\title{
Translating Traces with Innovative Thinking and giving an 'After-Life' to the Source Text
}

\author{
Abhinaba Chatterjee \\ Independent Research Scholar. ORCID ID: oooo-0003-4951-5753 \\ Email:abhinabaoooo@gmail.com
}

\begin{abstract}
In this paper, I attempt to show that deconstruction and its practices should not be read as intimations towards plurality or relativism in translation, but should rather be utilised as a powerful analytical tool, a way of reading and writing with heightened awareness. In order to arrive at this conclusion, I discuss différance and the play of the trace in the context of the cont(r)act between two texts that are in a relationship of translation. I further argue that plurality as contained in Derrida's différance is not a directive, but that the translator has to be aware of the existence of plurality and to take into account that the reader also participates in and contributes to this plurality.This has caused the binary oppositions such as original/translation, literal/free, alienating/naturalizing, etc., to lose ground and give way to new conceptualizations. The cultural turn in translation studies in the first half of the 1990s is an outcome of this paradigm shift. Moreover, the relations between translation and ideology, power, and identities have begun to hold a significant place in translation theory. I argue that all literature is subject to 'afterlife,' a continual process of translation. From this starting point, I seek to answer two questions. Firstly, how texts demonstrate this continual translation; secondly, how texts should be read if they are understood as constantly within translation. To answer these questions, I will develop a model of textuality that holds afterlife as central, and a model of reading based on this concept of textuality.
\end{abstract}

Keywords: Translation, Deconstruction, After-life, Textuality

The notion that translation is a creative process and subsequently that the translator is a creative artist, is gaining strength. Translation is now being looked upon as a process which enriches the source text and is equally productive. Brian Nelson and Brigid Maher opines that "The binary opposition of source oriented versus target oriented, for example, which dominated so much of Translation Studies discourse (some) twenty years ago[...] is increasingly outdated in a world of intense and accelerating globalisation, and it means less and less to those writing about translation today." (Nelson \& Maher, 2016, 1) Amongst the numerous approaches to study text, deconstruction has given the greatest impetus to this perspective of translation. By destabilising the 'sacred original', which is the source text, deconstruction provides endless possibilities of finding unlimited play of meanings and translating it into the target text.

Good translators are, in the first place, good readers. Tim Parks observes:

A translator reads with maniacal attention to nuance and cultural implication, conscious of all the books that stand behind this one; then he sets out to rewrite this impossibly complex thing in his own language, re-elaborating everything, changing everything in order that it remain the same, or as close as possible to his experience of the original. In every sentence the most loyal respect must combine with the most resourceful inventiveness. Imagine shifting the Tower of Pisa into downtown Manhattan and convincing everyone it's in the right place; that's the scale of the task. (Parks, Observer, 25 April 2010)

\footnotetext{
(c) AesthetixMS 2020. This Open Access article is published under a Creative Commons Attribution Non-Commercial 4.o International License (http://creativecommons.org/licenses/by-nc/4.o/), which permits non-commercial re-use, distribution, and reproduction in any medium, provided the original work is properly cited. For citation use the DOI. For commercial re-use, please contact editor@rupkatha.com.
} 
Translators, by virtue of their position as good readers, are aware of the numerous gaps and traces that are there to be explored, both in the source and the target texts. Translations undo the original (de Man, 1986) and in their rewriting require freedom to deal with the linguistic and by extension, cultural uniqueness of the source and target languages. Indeed, it is precisely this power that derives from its acute awareness of context and subjectivity that makes deconstruction invaluable to the practicing translator. Rather than being an "addition to the 'original", the translation is solicited by the original in order to fill a lack within the original itself.

Goethe believed that without outside influences national (and regional, in case of a nation like India) literatures would stagnate rapidly. Going by this belief, it can be argued, as Edith Grossman, in her book Why Translation Matter (2010) shows, that the very notion of literature is inconceivable without translation. The process of translation initiates a process of transmission which informs the entire history of literature. The question of 'equivalence', which was once considered the cornerstone of the process of translation, is now believed to be an outdated one. A translator's creativity is an essential element in the translation process as it incorporates "the original's mode of signification" (Benjamin, 1992: 79) and reconciles what might seem conflicting notions: fidelity and freedom. It is only after translations are accepted for what they are translations - that there can be greater freedom (Damrosch, 2003: 295).

The value of reading texts in the terms of 'afterlife' is to emphasise literature's immense potential, in terms of Derrida's readings of Benjamin's text, which includes criticism and other rewritings, or re-readings, of texts. Thus, all texts are continually translated in relation to language, history and textuality, and continually reveal further texts. Thus, the process of translation constantly defamiliarizes the 'source' text in addition to transferring it in the target language, which acts as a construct of creativity. This is readily apparent in the translation project of Gayatri Spivak, whose famous re-translation of "The Wet Nurse" as "Breast-giver" is, as Spivak (2003: 400) herself explains, "an example where attending to the author's stylistic experiments can produce a different text." Spivak's translation process reveal a creativity comprising the influence of experimental feminist writing on translation practice. She suggests that translators "go beyond translation to supplement their work" and make up "for the differences between various patriarchal languages by employing wordplay, grammatical dislocations and syntactic subversion in other places in their texts" (Von Flotow-Evans, 1997: 24). In cases such as these, creativity embodies with full force its primary tenor of the development of new and original ideas.

Another interesting case in point is the 1924 translation of Tagore's Gora, by Macmillan, London, which was apparently an English translation of the book published in 1909. This was at variance with the original magazine version serialized in Probashi, as it had already excluded many of its portions. While the book was being translated by WW Pearson during 1922-23, Tagore said in a letter that he was not sure about the English-reading public to see the importance of passages involving "scenes and sentiments which are foreign to them". However, the proposed changes were not carried out and the translation neither carried the abridgements that Tagore intended nor incorporated the revisions of the entire text.

But this seemingly full-length book with inaccuracies was the only English translation of the novel in circulation till 1997, when Sahitya Akademi asked Sujit Mukherjee to translate the full version of the text. Tagore didn't seem to really worry much about the incomplete text and the inauthentic translation. The fact that it gave him a presence in the English-speaking world was more important at that stage. The point to be noted here is that many of us have read only this version of the novel and Tagore's international reputation as a novelist at least has been created by a text that was doubly flawed. Thus, for people who read Tagore in translation only, there was 
no way to know that Tagore's finest novel was not the novel that one was supposed to have read. Broadly speaking, therefore, literature is sustained by translation; and, as Susan Bassnett has observed, there is something "curiously schizophrenic" about recognizing the central role of translation in shaping literature while downgrading it to a second-class literary activity (Bassnett 2006-2007). The case for translation as the shaping force of literature is made in a particularly compelling way by Susan Sontag in her essay, "The World as India", the essential argument of which is that a proper consideration of the art of translation is a claim for the value of literature itself:

My sense of what literature can be, my reverence for the practice of literature as a vocation, and my identification of the writer with the exercise of freedom - all these constituent elements of my sensibility are inconceivable without the books I read in translation from an early age. Literature was mental travel: travel into the past and to other countries. (Literature was the vehicle that could take you anywhere). And literature was criticism of one's own reality, in the light of a better standard. (Sontag 2007, 179)

As Nelson and Maher notes, "The cultural significance of translation could not be stated more clearly. Translation signifies encounters with otherness, bringing the 'foreign' closer." (Nelson \& Maher 2016, 5)

To a large degree, the limitations of translation are of a linguistic nature. But creativity is a construct that can overhaul the notion of untranslatability and give "voice to the intentio of the original not as reproduction but as harmony, as a supplement to the language in which it expresses itself" (Benjamin, 1992: 79). Foregrounded as translations, there are works such as Don Quixote or Memoirs of a Geisha which play upon the notion of the translation as a literary tool and use it as a literary strategy. In "Pierre Menard, Author of the Quixote" and "The Two Shores," both Borges and Fuentes respectively rely on their texts-as-translations to explore issues relating to the power of translation. In "Pierre Menard, Author of the Quixote," Borges anticipates relevance theory as he explores how the reader-translator informs a translation, in fact, any text, with personal and cultural history. As Menard sets out to recreate the Quixote, events after 1605 become part of the original. And so as in all original-translation dilemmas, Borges, who valued creative infidelities, considered how the original could in fact be unfaithful to the translation.

The process of translation, therefore, entails a reading that creates endless possibilities of production of meanings, by translating the 'traces' in the 'source text', which is the absent part of the sign's presence, the sign left by the absent thing, after it has passed on the scene of its former presence. Every present, in order to know itself as present, bears the trace of an absent which defines it. It follows then that an originary present must bear an originary trace, the present trace of a past which never took place, an absolute past. In this way, Derrida believes, he achieves a position beyond absolute knowledge. According to Derrida, the trace itself does not exist because it is self-effacing. That is, in presenting itself, it becomes effaced. Because all signifiers viewed as present in Western thought will necessarily contain traces of other (absent) signifiers, the signifier can be neither wholly present nor wholly absent. This is similar to other kinds of creative writing.

Translators are thus a mobile community who necessarily upset the traditional vocabulary comprising the sacredness of the 'original' and the 'translated'. Translation deals with an "original" and a translation insofar as a contract forged by the contact and subsequent continual rewriting exists between texts. However, the contract resulting from the contact between the two texts should not be viewed as a dichotomy between two binary opposites, but rather as a continuation, a relationship of mutual transformation, a symbiosis. In describing this cont(r)act, 
it is nevertheless important to define the relationship that obtains. Translation is more than the mere transformation of an "original". In Derrida's view, the process of translation transforms both "original" and translation and thereby ensures the survival of the "original". However, on the basis of this contract, the boundaries between "original" and translation are obscured as the survival of the "original" becomes intertwined with the survival of the translation. Through the translating text, the translation becomes an "original" itself, in the process also ensuring the survival of language.

As a result of the play of differences, any text becomes a footprint that contains in it traces of the past and future, but that can never be pinned to an "essence" or "fixed meaning". "It is because of différance," Derrida maintains,

... that the movement of signification is possible only if each so-called 'present' element, each element appearing on the scene of presence, is related to something other than itself, thereby keeping within itself the mark of its past element, and already letting itself be vitiated by the mark of its relation to the future element, this trace being related no less to what is called the future than to what is called the past, and constituting what is called the present by means of this very relation to what it is not: what it absolutely is not, not even a past or a future as a modified present (my emphases).(Derrida 1982, 13)

When we question this hierarchy, the notion of an "original" being inherently untouchable (in that its sanctity will be affected by any rewriting which will simply violate this sacred text in one way or another), is no longer sustainable. This is the case because any reading of a text changes it and each change triggers subsequent changes, just as any initial choice in a translation influences and determines the rest of the translation. Furthermore, the endless chain of signification (as signified becomes signifier ad infinitum), renders any attempt at closure futile and 'meaning-less'. Just as there is no transcendental signified for the deconstructionist, there are also 'no extralinguistic meanings'. This aspect obviously complicates the process of translation as well as the analysis and description of translations infinitely.

Almost always a positive notion, creativity in translation realizes the shifts which stem from the need to reformulate linguistic, stylistic and cultural particularities. In accommodating this difference, creative strategies redo originals and reposition translations in a global society wavering between the specific and the universal. Exploring creativity as part of an internationalized aesthetics or cultural commodification legitimizes the individual subjectivities which inform translations and opens up further discussion on the creative constructs in translation.

'Afterlife' suggests that textuality, translatability and translation are inextricable: for a text to exist is for a text to be within a state of potential for translation that is constantly enacted. This state of translatability, afterlife, is the condition of all texts, similarly to Derrida's claims about iterability, afterlife is here understood as a necessary condition of textuality. Within afterlife, a text is within a state of potential - the potential for that text to be augmented, since, following Derrida, no text is ever entirely complete. Such augmentations are translations. A translation is, thus, any text that fulfils a potential present in another text, resituating it in relation to language, history or textuality. The translator has his/her say by giving the author an afterlife. Some may think of this as a reward, a recognition, an acknowledgement not of authority but of affection, or of an opportunity. In any case, translation is a search for authority, a search for what Derrida calls not the perfect but the possible. 
5 | Translating Traces with Innovative Thinking and giving an 'After-Life' to the Source Text

\section{Works Cited}

Bassnett, Susan (2006-2007). "The Translator as Writer" Inaugural lecture, Facultat de Traduccio i interpretacio, Universitat Pompeu Fabra. http://www.upf.edu/factii/-pdf/Ilicons/bassnetto6o7.pdf (accessed 20 Aug 20)

Benjamin, W. 1992. The task of the translator. Trans. Harry Zohn. In: Schulte, R. \& Biguenet, J. (eds.) Theories of translation: An anthology of essays from Dryden to Derrida. Chicago: University of Chicago Press. p. 71-82.

Damrosch, David. What is world literature? Princeton: Princeton University Press, 2003.

Davis, K. 2001. Deconstruction and translation. Manchester : St. Jerome.s

De Man, Paul. 1986 The resistance to theory. Minneapolis: University of Minnesota Press.

Derrida, J. 1982. Margins of philosophy. Trans. Alan Bass. Brighton : Harvester.

--- 1985a. Des tours de Babel. Trans. Joseph F. Graham. In: Graham, J.F. (ed.) Difference in translation. Ithaca : Cornell University Press. p. 209-248.

---. 1985b. The ear of the other: Otobiography, transference, translation. Trans. Peggy Kamuf. New York : Schocken.

---. 2001. What is a "relevant" translation? Critical Inquiry, 27(2):174-200, Winter.

Even-Zohar, Itamar 1990. Polysystem Studies, Poetics Today, International Journal for Theory and Analysis of Literature and Communication, Volume 11, number 1 (1990)

Gentzler, E. 1993. Contemporary translation theories. London : Routledge.

Koskinen, K. 1994. (Mis)translating the untranslatable: The impact of deconstruction and poststructuralism on translation theory. Meta: Journal des Traducteurs/Translators' Journal, 39(3):446-452.

Mukherjee, Sujit 1981. Translation as Discovery and Other Essays on Indian Literature in English Translation. New Delhi, Allied Publishers.

Nelson, Brian and Brigid Maher (ed) (2016) Perspectives on Literature and Translation: Creation, Circulation, Reception, Routledge, New York and London (Special Indian Edition)

Parks, Tim (2010) "Why Translatorss Deserve Some Credit." Observer, 25 April

Pym, A. 1999. Doubts about deconstruction as a general theory of translation. [Web:] http://www.fut.es/ apym/on-line/decon.html [Date of access: 2o August 2018].

--- 2000. European translation studies, une science qui dérange, and why equivalence needn't be a dirty word. [Web:] http://www.fut.es/ apym/deranger.html [Date of access: 21 August 2018].

Sontag, Susan (2007) "The World as India" in At the Same Time: Essays and Speeches, 156-179, London: Hamish Hamilton

Venuti, L. (ed.) 1992. Rethinking translation: Discourse, subjectivity, ideology. London : Routledge.

--- (ed.) 200o. The translation studies reader. London : Routledge.

--- 2001. Introduction. Critical Inquiry, 27(2):169-173, Winter.

Abhinaba Chatterjee holds a Masters degree in English Literature and Translation Studies from Calcutta University \& Annamalai University respectively and an M. Phil degree from Delhi University. He has published extensively on various fields of English literature, including Shakespeare, Indian Writings in English (IWE) and postcolonial theory. He has also presented papers in many National and International seminars, both in India and abroad. He is particularly interested in Indian Writings in English, Modernity in Indian Literature, Modern Drama, Postcolonial Literature and Translation Studies. 